\title{
Manajemen Perpustakaan Sekolah Untuk Sumber Belajar Peserta Didik
}

\author{
Mohamad Muspawi ${ }^{1}$, Engla Okta Piana ${ }^{2}$ \\ Dosen FKIP Universitas Jambi ${ }^{1}$ \\ Email: muspawi01@gmail.com \\ Mahasiswa FKIP Universitas Jambi ${ }^{2}$ \\ Email: Engla_star@gmail.com
}

\begin{abstract}
This research background of the fact that the author of the initial encounter on the ground that the SDN 13 / I Muarabulian has sought to provide library facilities for learners. But the efforts of the school in providing library services yet provide maximum results. The school library is still rarely visited by students to be used as a learning resource. The purpose of this study was to describe the management of the library as a source for students at SDN 13 / I Muarabulian. This research method is descriptive qualitative research with the principal subject of one person, and one person librarians. The method used in this research is qualitative method. The data collection technique using observation technique, documentation, and interviews. To check the validity of the data, the authors do diligence observation, triangulation, member check, audit trail. And to analyze the data, the authors conducted a review and data reduction, the unitization of data, categorization data, and interpretation of data. The results of this study indicate that the management of the library as a learning resource has not run optimally. Some aspects of library management still has many shortcomings such as building libraries of the schools are still small and narrow and has a size of about 20 square meters with details of length of 5 meters and a width of 4 meters, tools and equipment that is not yet complete, only the wastebasket, stamp library, library stamp and stamp inventory. While supplies libraries owned namely wardrobes, tables, and chairs, room layout library focuses only on the arrangement of tables, chairs study and library, the collection of library materials is still a little in the form of books and non-books and library collections which contains fiction and non-fiction, lack of librarians, the service is still not controlled, and the absence of clear rules library. Based on the research that has been done, it can be concluded that the management of the library as a learning resource has not run optimally because it still has many shortcomings.
\end{abstract}

Keywords: Management, Library, Learning Resources.

\section{PENDAHULUAN}

Manusia dilahirkan ke dunia ini dalam keadaan tidak berpengetahuan, tetapi dibekali dengan sarana baik fisik maupun psikis. Sarana dan bekal tersebut membuat manusia mampu untuk mendapatkan hal-hal baru yang akan merubah dirinya dari yang awalnya tidak tahu menjadi tahu. Manusia yang ingin memperoleh pengetahuan tersebut harus melalui sebuah proses yaitu belajar.
Sugihartono, dkk

(2007:74) menyatakan bahwa belajar merupakan suatu proses memperoleh pengetahuan dan pengalaman yang kemudian diwujudkan melalui perubahan tingkah laku dan kemampuan bereaksi yang sifatnya relatif permanen atau menetap karena adanya interaksi individu dengan lingkungannya. Muhibinsyah (2006:68) menjelaskan belajar secara umum dapat dipahami sebagai sebuah tahap perubahan seluruh tingkah laku individu yang sifatnya relatif menetap 
sebagai hasil pengalaman dan interaksi dengan lingkungan yang melibatkan proses kognitif.

Belajar pada dasarnya adalah kebutuhan primer manusia. Kondisi alam dan sosial yang selalu berubah setiap waktu menjadi penyebab manusia wajib untuk belajar. Manusia dapat mencapai berbagai macam kompetensi, ketrampilan dan sikap yang diperlukannya untuk tetap survive dengan belajar. Semakin banyak manusia belajar, semakin berkembang potensi dan kemampuan yang dimilikinya. Sebaliknya, semakin sedikit manusia belajar semakin kecil peluang yang dimilikinya untuk mengembangkan potensi dan kemampuannya.

Belajar merupakan kegiatan yang berproses dan merupakan unsur yang sangat fundamental dalam pelaksanaan pendidikan. Ini berarti, berhasil tidaknya pencapaian tujuan pendidikan itu sangat bergantung pada proses belajar yang dialami siswa baik ketika ada di sekolah maupun di lingkungan rumahnya. Oleh karena itu, pemahaman yang benar mengenai aspek, prinsip, dan cara belajar mutlak diperlukan oleh para pendidik. Kesalahan atau ketidaklengkapan pemahaman pendidik terhadap proses belajar dan hal-hal yang berkaitan dengannya akan mengakibatkan kurang maksimalnya hasil belajar yang dicapai peserta didik.

Kegiatan pembelajaran pada dasarnya merupakan usaha untuk membimbing siswa untuk aktif belajar, sebab siswa adalah subjek yang merencanakan sekaligus yang melaksanakan belajar. Prinsip belajar aktif adalah salah satu prinsip belajar yang harus dipahami oleh penyelenggara pendidikan seperti sekolah. Sekolah memiliki tugas untuk membantu siswa untuk aktif dalam belajar. Sekolah hendaknya mengajarkan ketrampilan dasar belajar dengan baik seperti misalnya ketrampilan membaca, mengamati, dan mendengarkan, dan memahami komunikasi non verbal. Sekolah juga harus mengajarkan ketrampilan dasar intelektual, seperti mengadakan penalaran, berpikir kritis, dan menafsirkan data. Semua kemampuan tersebut akan membantu mereka untuk mampu belajar di mana saja di luar pembelajaran di kelas dengan memanfaatkan sumber-sumber belajar yang banyak dijumpai dalam kehidupan.

Suharjo (2006:107) menyatakan sumber belajar adalah segala sumber (data, manusia, dan benda) yang dapat digunakan oleh siswa untuk membantu belajar baik secara mandiri maupun bersama-sama, biasanya dalam suatu cara yang informal. Sumber belajar tidak hanya dapat digunakan di dalam kelas. Sumber belajar juga dapat digunakan di luar kelas dengan memanfaatkan berbagai macam sumber belajar yang relevan dengan pembelajaran, karena proses belajar mengajar tidak hanya berlangsung di dalam kelas tapi juga di luar kelas.

Sumber belajar merupakan faktor ekternal yang sangat mempengaruhi hasil belajar. Tanpa ada sumber belajar tidak akan ada proses pembelajaran, karena setiap kegiatan belajar menghendaki adanya interaksi antara siswa dengan sumber belajar. Guru merupakan sumber belajar utama dengan segala kemampuan, wawasan keilmuan, dan ketrampilannya, tetapi siswa juga membutuhkan sumber belajar lain yang dapat menambah pengetahuannya dan melatih kemandiriannya dalam belajar. Sekolah harus menyediakan alternatif sumber belajar yang dapat digunakan oleh siswa. Salah satu alternatif sumber belajar yang harus disediakan sekolah adalah perpustakaan. Keberadaan perpustakaan memiliki peran penting dalam pendidikan seperti yang tercantum dalam Undangundang Republik Indonesia pasal 43 tahun 2007 pasal 1 tentang perpustakaan bahwa perpustakaan adalah institusi pengelola koleksi karya tulis, karya cetak, dan/karya rekam secara profesional dengan sistem 
yang baku guna memenuhi kebutuhan pendidikan, penelitian, pelestarian, informasi, dan rekreasi para pengguna.

Keberadaan perpustakaan di sekolah dasar sangat bermanfaat bagi peningkatan kualitas pembelajaran. Perpustakaan dapat memberikan kesempatan bagi siswa dan guru untuk memperdalam ilmu pengetahuan dan teknologi. Hal ini dikarenakan tidak semua informasi ataupun pengetahuan dapat diraih saat pembelajaran di kelas, sehingga perpustakaan menjadi alternatif sumber belajar untuk menunjang proses pembelajaran. Pemanfaatan perpustakaan yang optimal diharapkan akan dapat membantu tugas siswa dan meringankan tugas dari guru.

Menurut

Bafadal (2005:5)

keberhasilan perpustakaan sekolah dalam menyelenggarakan pelayanan sumber belajar yang baik memang lebih terfokus pada penataan dan pengelolaan kerjanya, akan tetapi dalam pelaksanaanya perpustakaan sekolah yang baik harus menyediakan layanan dan sarana yang memadai. Layanan yang idealnya ada dalam perpustakaan sekolah antara lain adalah sebagai berikut: 1) Gedung atau ruang perpustakaan, 2) Peralatan dan perlengkapan perpustakaan, 3) Tata ruang perpustakaan, 4) Koleksi bahan pustaka, 5) Tenaga pustakawan, 6) Pelayanan perpustakaan, 7) Tata tertib perpustakaan.

Berdasarkan hasil observasi awal yang peneliti lakukan, SDN 13/I Muara Bulian telah berupaya untuk menyediakan fasilitas perpustakaan bagi peserta didiknya. Upaya ini sangat penting dilakukan untuk menambah referensi belajar bagi siswa karena sebagian besar siswa di SDN 13/I Muara Bulian berasal dari daerah yang masih memiliki fasilitas belajar yang minim.

Minimnya fasilitas belajar umum di daerah tempat tinggal siswa SDN 13/I Muara Bulian praktis menjadikan perpustakaan sekolah sebagai sumber belajar yang sangat penting bagi siswa. Namun upaya yang dilakukan sekolah dalam memberikan pelayanan perpustakaan belum memberikan hasil yang maksimal. Perpustakaan sekolah masih jarang dikunjungi oleh siswa untuk digunakan sebagai sumber belajar. Masih jarangnya siswa yang mengunjungi perpustakaan menjadi problematika yang harus segera diselesaikan oleh sekolah selaku penyelenggara perpustakaan. Tujuan yang ingin dicapai dalam penelitian ini adalah "Mendeskripsikan pelaksanaan pengelolaan perpustakaan sebagai sumber belajar siswa di SDN 13/I Muara Bulian”.

\section{METODE PENELITIAN \\ Pendekatan Penelitian}

Penelitian ini menggunakan pendekatan kualitatif yang bertujuan untuk mengkaji permasalahan dan memperoleh makna yang lebih mendalam sesuai dengan latar penelitian. Sugiyono (2009:9) menjelaskan metode penelitian kualitatif adalah metode penelitian yang berlandaskan pada filsafat post-positivisme, digunakan untuk meneliti pada kondisi obyek yang alamiah, dimana peneliti adalah sebagai instrumen kunci, teknik pengumpulan data dilakukan secara triangulasi (gabungan), analisis data bersifat induktif atau kualitatif, dan hasil penelitian kualitatif lebih menekankan makna dari pada generalisasi.

\section{Subjek Penelitian.}

Adapun subjek dalam penelitian ini adalah kepala sekolah, dan pustakawan SDN 13/I Muara Bulian. Sedangkan yang menjadi objek penelitian ini perpustakaan SDN 13/I Muara Bulian.

\section{Teknik Pengumpulan Data}

Pengumpulan data penelitian ini menggunakan tiga teknik utama, yaitu observasi, wawancara, dan studi dokumentasi. 


\section{Observasi}

Observasi penulis lakukan secara berkelanjutan agar diperoleh informasi dari tangan pertama mengenai masalah yang diteliti dan kondisi SDN 13/I Muara Bulian. Untuk itu, penulis melakukan pengamatan partisipasi aktif dan pasif secara bergantian dengan memperhatikan sifat situasi dan peristiwa yang diamati serta keterlibatan penulis dengan responden.

\section{Wawancara}

Pelaksanaan wawancara pada prinsipnya dimaksudkan untuk mendapatkan data yang cukup sehubungan dengan pokok masalah penelitian yang telah diidentifikasi. Kegiatan wawancara ini penulis lakukan secara terus menerus dengan responden dalam berbagai situasi, meskipun kadangkala dilakukan pula dalam situasi yang khsusus.

Tipe wawancara yang lebih banyak penulis lakukan dalam proses pengumpulan data ini adalah wawancara tak terstruktur, terfokus pada suatu masalah tertentu dan berisi pertanyaan-pertanyaan yang berpindah-pindah dari satu pokok ke pokok lain, sepanjang berkaitan dengan masalah yang diteliti serta menjelaskan aspekaspeknya.

Studi Dokumentasi

Selain observasi dan wawancara, penulis menggunakan pula teknik pengumpulan data melalui studi dokumentasi. Data yang diperoleh dari studi dokumentasi, penulis manfaatkan sebagai bahan triangulasi untuk pengecekan kesesuaian data.

Untuk memilih dokumen sebagai sumber data, penulis mendasarkan diri kepada kriteria sebagai berikut: keotentikan isi dokumen, isi dokumen dapat diterima sebagai suatu kenyataan, dan kecocokan atau kesesuaian data untuk menambah pengertian tentang masalah yang diteliti.

\section{Proses Pengumpulan Data}

Proses pengumpulan data dalam penelitian ini penulis tempuh melalui tahap orientasi dan overview, tahap eksplorasi (focused exploration), dan tahap member check.

Tahap pertama, orientasi dan overview. Pada tahap ini penulis mencari dan mengumpulkan informasi yang diperlukan untuk menetapkan fokus penelitian. Untuk itu penulis mempelajari berbagai dokumen termasuk kajian teoretik, wawancara dan observasi yang bersifat umum. Selanjutnya, menelaah informasi yang diperoleh untuk menemukan hal-hal yang menarik dan bermanfaat bagi penelitian selanjutnya.

Tahap kedua, eksplorasi (focused exploration). Pada tahap ini, penulis mempertajam fokus penelitian agar pengumpulan data lebih terarah dan spesifik. Pada tahap ini, penulis melakukan wawancara untuk memperoleh informasi yang lebih mendalam mengenai aspek-aspek empirik yang ingin diungkap oleh fokus penelitian. Selanjutnya, mengobservasi halhal yang dianggap terkait dengan fokus penelitian, dan memastikan keterkaitan antara hasil penelaahan berbagai dokumen dengan fokus penelitian.

Untuk lebih komprehensifnya keterangan lapangan, penulis pun meminta bantuan informan yang berkemampuan dan memiliki pengetahuan yang luas mengenai aspek-aspek tertentu dari fokus penelitian ini, sehingga didapatkan data dan informasi yang lebih mendalam.

Tahap ketiga, member check. Dimaksudkan untuk mengecek kebenaran data atau informasi yang dikumpulkan. Tahap ini merupakan tahap untuk memperoleh kredibilitas hasil penelitian. Tahap ini cukup penting karena data harus diakui dan diterima kebenarannya oleh sumber informasi, dan oleh sumber atau informan lainnya. 


\section{Pengecekan Kesahihan Data}

Untuk mengecek kesahihan atau keterpercayaan data penelitian ini, penulis menggunakan kriteria sebagai berikut: (1) kredibilitas/derajat kepercayaan, transferabilitas/ keteralihan, dependabilitas/ ketergantungan, dan konfirmabilitas/ kepastian.

Untuk memeriksa kesahihan data hasil penelitian ini penulis menempuh cara-cara berikut ini: 1. Ketekunan pengamatan. 2. Triangulasi. 3. Member check. 4. Audit trail.

\section{Analisis Data}

Analisis data yang penulis lakukan, mengikuti proses sebagaimana yang dianjurkan oleh Moleong (1998: 37), yaitu dimulai dengan menelaah seluruh data yang tersedia dari berbagai sumber, yaitu dari wawancara dan pengamatan yang sudah dituliskan dalam catatan lapangan, dokumen pribadi, dokumen resmi, gambar, foto, dan sebagainya. Adapun prosedur analisis data yang penulis tempuh dalam penelitian ini terdiri atas empat langkah berikut ini, yaitu: 1. Penelaahan dan reduksi data. 2. Unitisasi data. 3. Kategorisasi data. 4. Interpretasi data.

\section{HASIL DAN PEMBAHASAN}

Pelaksanaan Manajemen Perpustakaan sebagai Sumber Belajar di SDN 13/I Muara Bulian

\section{Gedung atau Ruang Perpustakaan}

Gedung atau ruang merupakan salah satu komponen yang harus dimiliki oleh yang berfungsi sebagai tempat untuk menyimpan koleksi bahan pustaka, tempat kerja pustakawan, dan ruang baca siswa pengguna perpustakaan.

\section{Luas Gedung atau Ruangan}

Berdasarkan hasil wawancara dengan pustakawan pada tanggal 26-28 April 2016, diketahui bahwa perpustakaan saat ini menggunakan ruangan bekas kantor guru yang belum memadai dan belum memenuhi syarat. Pustakawan berpendapat bahwa "luas ruang yang harus dimiliki perpustakaan yang ideal minimal berukuran 46 meter persegi".

Pernyataaan ini diperkuat dengan pernyataan kepala sekolah yang menyatakan bahwa "luas ruang yang digunakan untuk perpustakaan masih sangat sempit, karena hanya berukuran $4 \times 5$ meter persegi".

Pada tanggal 26-28 April 2016 pustakawan memberikan keterangan bahwa untuk kondisi sementara ini ruang perpustakaan masih belum memadai karena hanya memakai ruang lama yang tidak didesain untuk ruang perpustakaan sehingga ukuran ruangannya masih terlalu kecil dan sempit. Hal tersebut diperkuat dengan hasil observasi yang peneliti lakukan pada tanggal 2-4 April 2016 bahwa ruang perpustakaan yang dimiliki sekolah masih berukuran kecil dan sempit. Ruangan yang digunakan untuk perpustakaan memiliki ukuran sekitar 20 meter persegi dengan rincian panjang 5 meter dan lebar 4 meter.

Berdasarkan dari hasil wawancara dan observasi dapat ditarik kesimpulan bahwa ruangan perpustakaan di SDN 13/I Muara Bulian memiliki masih tergolong sempit karena hanya memiliki luas sekitar 20 meter persegi.

\section{Pemilihan Lokasi}

Pustakawan menyatakan bahwa pemilihan ruang perpustakaan didasarkan pada ketersediaan ruangan kosong yang dimiliki oleh sekolah. Ruangan yang sekarang digunakan perpustakaan merupakan ruang lama yang tidak terpakai.

Pernyataan pustakawan tersebut didukung oleh kepala sekolah yang memberikan keterangan "Karena ruang di sana kosong dan tidak digunakan, jadi dipakai untuk perpustakaan”. Demikian juga pada 16-18 Mei 2016 pustakawan menyatakan bahwa "Itu bukan ruang yang 
dibangun untuk perpustakaan. Karena mungkin terbatasnya ruang yang ada di sini jadi milih ruangan yang di sebelah pojok itu".

Kepala sekolah pun tidak membantah pernyataan tersebut dengan mengungkapkan bahwa pemilihan ruang perpustakaan dilakukan melalui mekanisme pertemuan dewan guru dan tenaga perpustakaan. Pertemuan tersebut membahas segala hal terkait perpustakaan termasuk pemilihan ruang perpustakaan.

Data tersebut diperkuat oleh hasil observasi pada tanggal 9-12 Mei 2016 menunjukkan bahwa sekolah hanya memiliki ruang yang terbatas. Sekolah hanya mempunyai 9 buah ruangan. 6 buah ruangan sebanyak 6 ruangan sudah terpakai untuk ruang kelas, 1 ruangan untuk kantor, 1 ruangan untuk UKS, dan 1 ruangan untuk perpustakaan.

Dari hasil wawancara dan observasi, penulis mengetahui bahwa lokasi perpustakaan yang saat ini digunakan masih kurang strategis. Pertimbangan yang digunakan dalam pemilihan lokasi perpustakaan adalah faktor kondisi ruangan yang dimiliki oleh sekolah, sehingga memaksa sekolah untuk menggunakan ruangan yang sebenarnya bukan didesain untuk perpustakaan menjadi ruang perpustakaan.

\section{Pemeliharaan Gedung atau Ruangan}

Berdasarkan pada tanggal 23 Mei 2016 peneliti memberikan pertanyaan tentang bagaimana pelaksanaan pemeliharaan perpustakaan sekolah, pustakawan memberikan keterangan kepada peneliti bahwa "Ya kadang saya bersihkan, disapu dan dihilangkan debunya". Pernyataan ini menunjukkan bahwa kegiatan pemeliharaan ruang perpustakaan masih belum berjalan dengan rutin dan baik.

Pendapat tersebut diperkuat dengan keterangan dari kepala sekolah pada tanggal
23 Mei 2016 yang menyatakaan bahwa pemeliharaan ruang perpustakaan "Sudah ada pustakawan yang mengelola, namun sekarang pustakawan masih sekolah, sehingga kadang tidak berangkat". Ketidakhadiran dari pustakawan inilah yang menyebabkan program pemeliharaan ruang perpustakaan menjadi terhambat.

Sedangkan hasil observasi pada pengamatan II, III, IV, V, VI dan VII menunjukkan bahwa kondisi ruang perpustakaan sekolah masih kotor dan kurang tertata dengan rapi. Selama pengamatan tersebut peneliti belum melihat adanya kegiatan pemeliharaan ruangan yang dilakukan baik oleh pustakawan, penjaga sekolah maupun dari siswa.

Dari hasil wawancara dan observasi tersebut dapat diambil kesimpulan bahwa sekolah sudah memiliki program pemeliharaan ruang perpustakaan yang menjadi tanggungjawab pustakawan. Namun program pemeliharaan tersebut belum dilaksanakan secara rutin oleh pustakawan sehingga ruang perpustakaan masih kotor dan tidak tertata dengan rapi.

\section{Penyediaan Peralatan dan Perlengkapan Perpustakaan}

Hasil wawancara dengan pustakawan menunjukkan bahwa kepemilikan peralatan dan perlengakapan perpustakaan di sekolah masih kurang memadai. Pustakawan pada tanggal 24 Mei 2016 menjelaskan bahwa

"perpustakaan hanya memiliki peralatan berupa peralatan tahan lama, yakni stempel perpustakaan, dan stempel inventaris, sedangkan perlengkapan perpustakaan hanya ada meja, almari bekas, kursi dan tikar".

Pernyataan pustakawan tersebut sesuai dengan pernyataan kepala sekolah pada tanggal 24 Mei 2016 yang menyatakan bahwa "Peralatan yang dimiliki sekolah belum ada juga. Selama ini kalau mau menggunakan, ya menggunakan peralatan 
kantor". Sedangkan ketika ditanya mengenai perlengkapan perpustakaan, kepala sekolah menyatakan "Ada rak buku lama, kursi, meja, dan juga ada tikar yang bisa digunakan ketika membaca".

Hasil observasi tidak jauh berbeda dengan hasil wawancara pustakawan, kepala sekolah. Pada pengamatan III diketahui bahwa sekolah belum memiliki peralatan perpustakaan habis pakai. Peralatan elektronik yang dimiliki sekolah masih terbatas. Sebagai contoh fasilitas komputer dan tape recorder, sekolah hanya memiliki satu buah saja, sehingga memang untuk pengalokasian peralatan elektronik untuk perpustakaan belum ada.

Hasil observasi di perpustakaan peneliti tidak menemukan stempel perpustakaan dan stempel inventaris. Peneliti kemudian menanyakan hal tersebut kepada pustakawan, lalu peneliti mencari dan menemukan peralatan tersebut berada di kantor guru.

Berdasarkan hasil wawancara dan observasi di atas dapat ditarik kesimpulan bahwa peralatan perpustakaan yang dimiliki oleh sekolah adalah keranjang sampah, stempel perpustakaan, stempel perpustakaan dan stempel inventaris. Sedangkan perlengkapan perpustakaan yang dimiliki yaitu almari, meja, dan kursi.

\section{Tata Ruang Perpustakaan}

Hasil wawancara dengan pustakawan pada tanggal 24 Mei 2016 menyebutkan bahwa penataan ruang perpustakaan hanya berfokus pada penataan meja, kursi belajar dan ruang perpustakaan saja. Hal ini dikarenakan perpustakaan belum memiliki ruang kerja petugas perpustakaan. Pustakawan menyatakan bahwa "Ruang kerja seringnya saya di kantor guru, kalau di perpustakaan cuma kadang-kadang kalau lagi merapikan atau menata koleksi buku disana". Sedangkan dalam penataan meja dan kursi belajar serta ruang perpustakaan perpustakaan menjelaskan "Penataannya ya disendirikan dari tempat koleksi buku, dipinggirkan biar anak bisa membaca di sana".

Hasil wawancara dengan kepala sekolah juga menyebutkan bahwa ruang kerja petugas di perpustakaan belum ada, dan petugas masih berada di kantor. Selain itu, kepala sekolah menyerahkan tanggungjawab penuh terkait penataan perpustakaan kepada pustakawan.

Berdasarkan Pengamatan III, IV, V, dan VI juga diperoleh yang menunjukkan bahwa perpustakaan belum memiliki ruang kerja petugas perpustakaan. Dalam keperluan pengerjaan tugasnya pustakawan menggunakan ruang perpustakaan dan kantor bersama dengan guru.

Hasil wawancara dan observasi di atas menunjukkan bahwa di dalam perpustakaan belum terdapat ruang kerja petugas perpustakaan. Sedangkan, penataan meja dan kursi telah berdampingan dengan koleksi buku, serta penerangan dan sirkulasi udara ruangan sudah baik. Akan tetapi, di atas meja masih ditemukan buku-buku yang berantakan dan alat musik, sehingga mengganggu kenyamanan siswa yang belajar di perpustakaan.

\section{Koleksi bahan pustaka}

Hasil wawancara dengan pustakawan pada tanggal 24 Mei 2016 menyebutkan bahwa sekolah memiliki koleksi bahan pustaka baik yang bentuknya berupa buku atau non buku, maupun yang isinya fiksi dan non fiksi. Koleksi bahan pustaka yang dimiliki sekolah berjumlah sekitar 300 buah.

Hal ini sesuai dengan pernyataan kepala sekolah bahwa "Koleksi bahan pustaka ada buku dan ada beberapa peta di sana, namun untuk koleksi non buku memang masih terbatas. Buku fiksi dan non fiksi ada, namun kebanyakan adanya buku pelajaran. Buku cerita masih kurang". (tanggal 24 Mei 2016). 
Hasil observasi tidak terlalu berbeda dengan hasil wawancara. Pada Pengamatan II, III, dan V didapat data bahwa koleksi bahan pustaka yang dimiliki perpustakaan sebagian besar berupa buku. Koleksi bahan pustaka yang berupa non buku yang dimiliki perpustakaan hanya peta Indonesia 3 dimensi.

Pada Pengamatan II, III, dan V diperoleh data bahwa perpustakaan sekolah memiliki banyak koleksi bahan pustaka non fiksi. Kebanyakan koleksi tersebut adalah buku pelajaran. Jumlah buku pelajaran yang terdapat di perpustakaan hampir satu lemari penuh. Sedangkan koleksi bahan pustaka fiksi yang dimiliki sekolah jumlahnya masih sedikit.

Dari wawancara dan observasi di atas, peneliti dapat menyimpulkan bahwa koleksi bahan pustaka yang dimiliki sekolah antara lain adalah koleksi bahan pustaka berupa buku dan non buku. Sekolah juga terlah memiliki koleksi bahan pustaka yang berisi fiksi dan non fiksi.

\section{Tenaga Pustakawan}

Berdasarkan wawancara dengan kepala sekolah, pada tanggal 25 Mei 2016 diperoleh data bahwa selain melakukan pemeliharaan ruang perpustakaan pustakawan juga diberi tugas untuk mengelola koleksi bahan pustaka, dan perangkat perpustakaan. Kepala sekolah berpendapat bahwa pustakawan telah melaksanakan tugasnya dengan baik.

Hal ini sedikit bertentangan dengan pengakuan pustakawan yang menyatakan bahwa pengelolaan buku telah dikelola dengan tahap-tahap sebagai berikut. "Buku masuk dicatat dibuku induk, distempel perpustakaan dan inventaris, lalu dimasukkan datanya ke aplikasi Slims. Kemudian dicetak label buku, dilabeli, baru dilayankan di perpustakaan". Akan tetapi terkait pembuatan perangkat perpustakaan, pustakawan memberi keterangan "Kalau perangkat seperti kartu anggota sudah saya desain, namun belum saya cetak, belum ada dana. Kalau buku pengunjung sudah ada, namun belum saya taruh di perpustakaan". (tanggal 25 Mei 2016)

Berdasarkan Pengamatan II, III, dan V, diperoleh data bahwa pustakawan telah melakukan pengelolaan koleksi bahan pustaka. Koleksi bahan pustaka telah diberi label , dimasukkan dalam buku induk perpustakaan, dan ditata dalam almari perpustakaan. Namun ketika ditanya terkait komputerisasi perpustakaan, pustakawan menunjukkan bahwa data koleksi bahan pustaka belum dimasukkan dalam aplikasi Slims dalam komputer. Pustakawan kemudian menunjukkan desain kartu anggota perpustakaan yang telah dibuat di dalam komputer.

Berdasarkan hasil wawancara dan observasi di atas, peneliti mengambil kesimpulan bahwa pustakawan telah melakukan pengelolaan bahan pustaka, dan telah membuat perangkat perpustakaan, akan tetapi beberapa perangkat perpustakaan masih dalam tahap pembuatan. Bahan pustaka yang dikelola oleh pustakawan sudah bisa digunakan siswa di perpustakaan, sedangkan perangkat perpustakaan masih belum digunakan.

\section{Pembiayaan}

Hasil wawancara dengan pustakawan pada tanggal 25 Mei 2016 yang menyebutkan bahwa "Dana pembiayaan perpustakaan berasal dari BOS, dengan besaran biayanya tidak tentu". Selama ini sekolah juga belum pernah melakukan penarikan dana dari orang tua atau siswa untuk pembiayaan perpustakaan.

Hal ini dibenarkan oleh kepala sekolah pada tanggal 25 Mei 2016 yang memberikan keterangan bahwa "Selama ini kami belum menarik dana dari siswa maupun orangtual wali murid". Selain itu, kepala sekolah menambahkan tentang dana alternatif yang 
digunakan untuk pembiayaan perpustakaan adalah dengan cara mengajukan proposal melalui dinas pendidikan. Pengajuan proposal ini telah membuahkan hasil untuk tahun ini, sekolah telah mendapat bantuan untuk biaya pembangunan gedung sekolah baru.

Selama melakukan observasi pada pengamatan I sampai VIII peneliti tidak menemukan data tentang pembiayaan perpustakaan. Peneliti tidak menemukan dokumen yang berisi data anggaran perpustakaan ataupun praktek pemungutan biaya dari guru kepada siswa maupun wali murid.

Peneliti mengambil kesimpulan dari hasil wawancara dan observasi bahwa sumber dana utama pembiayaan pengelolaan perpustakaan berasal dari dana BOS (Bantuan Operasional Sekolah). Selain itu ada juga dana lain yang bisa digunakan yakni melalui pengajuan proposal bantuan melalui dinas pendidikan.

\section{Pelayanan perpustakaan}

Pustakawan pada tanggal 9-12 Mei 2016 menjelaskan bahwa sekolah memberikan layanan perpustakaan setiap hari mengikuti jam sekolah. Layanan yang dimaksud adalah layanan peminjaman bahan pustaka, layanan referensi, dan layanan fasilitas ruang baca.

Hasil wawancara kepada kepala sekolah pada tanggal 25 Mei 2016 membenarkan hal tersebut dengan memberikan penjelasan bahwa "Kalau pelayanan kita tetap berikan pada siswa setiap hari. Kita utamakan pada saat istirahat, namun boleh ketika pelajaran dengan pengawasan dari guru". Selanjutnya kepala sekolah menerangkan bahwa sekolah telah memiliki fasilitas ruang baca dan referensi, sedangkan untuk layanan peminjaman bahan pustaka sekolah telah melaksanakannya dengan memberikan batasan waktu peminjaman selama satu minggu.

Hasil wawancara dengan pustakawan menghasilkan keterangan bahwa layanan referensi di perpustakaan telah tersedia kamus, namun untuk ensiklopedi belum ada. pustakawan kemudian menerangkan tentang kondisi ruang baca saat ini "Kalau ruangan tersendiri belum ada, siswa kalau membaca ya menggunakan meja dan kursi yang ada di sana". (tanggal 25 Mei 2016)

Berdasarkan hasil observasi pada Pengamatan II, III, IV, V, dan VI Sekolah membuka layanan perpustakaan setiap hari selama jam sekolah berlangsung. Layanan tersebut mulai dilaksanakan tepat saat penjaga gerbang membuka semua pintu ruang kelas dan perpustakaan setiap hari.

Dari hasil wawancara dan observasi di atas, peneliti mengambil kesimpulan bahwa sekolah telah melaksanakan pelayanan perpustakaan setiap hari selama jam sekolah berlangsung. Layanan perpustakaan yang diberikan sekolah yaitu layanan peminjaman bahan pustaka, layanan referensi, dan layanan fasilitas ruang baca.

\section{Tata Tertib Perpustakaan}

Hasil wawancara dengan pustakawan pada tanggal 25 Mei 2016, diperoleh data bahwa sekolah telah memiliki tata tertib perpustakaan, tetapi tata tertib tersebut belum ditulis dan ditempel di perpustakaan. Tata tertib perpustakaan tersebut disampaikan kepada siswa secara lisan. Bagi pelanggar tata tertib selama ini pustakawan menjelaskan bahwa "Belum ada sanksi. Karena belum diawasi juga. Siswa mau membaca di perpustakaan saja sudah bagus. Saya sudah senang”.

Kepala sekolah pada tanggal 18 Mei 2016 memberikan keterangan bahwa "Untuk tata tertib ada, misal bila ada buku yang rusak atau hilang menjadi tanggungjawab peminjam. Itu sudah kami sampaikan kepada siswa". Ketika ditanya terkait 
pemberian sanksi kepala sekolah juga membenarkan pernyataan dari pustakawan bahwa pemberian sanksi memang belum diberlakukan.

Hasil observasi pada Pengamatan III menunjukkan bahwa sekolah belum menempel papan tata tertib perpustakaan. Beberapa siswa masih ada yang sering berbuat gaduh di dalam perpustakaan, bahkan ada siswa yang memainkan alat musik di dalam perpustakaan. Selanjutnya pada Pengamatan III, IV, V, dan VI diperoleh data bahwa sekolah belum melakukan pengawasan dalam pelayanan perpustakaan sehingga pemberian sanksi kepada pelanggar tata tertib belum dapat dilaksanakan.

Dari hasil wawancara dan observasi diatas, peneliti mengambil kesimpulan bahwa tata tertib yang dimiliki sekolah belum jelas karena belum ada tata tertib perpustakaan yang tertulis dan tertempel di perpustakaan. Penegakkan tata tertib dengan pemberian sanksi pun juga belum dilaksanakan..

\section{PEMBAHASAN}

Pelaksanaan Pengelolaan Perpustakaan sebagai Sumber Belajar di SDN 13/I Muara Bulian

\section{Gedung atau Ruang Perpustakaan}

Luas Gedung atau Ruangan

Luas ruangan perpustakaan yang dimiliki sekolah kurang lebih berukuran 20 meter persegi. Kondisi ruangan ini masih tergolong kurang memenuhi syarat dikarenakan dalam peraturan Menteri Pendidikan Nasional no. 24 Tahun 2007 tentang standar sarana dan prasarana untuk SD/MI, SMP/MTs dan SMA/MA, luas ruangan perpustakaan sekolah minimal 56 meter persegi dengan lebar minimal 5 meter.

Luas ruangan yang belum memenuhi syarat ini tentu mengakibatkan perpustakaan tidak dapat menjalankan fungsinya dengan optimal. Bagi pustakawan sempitnya ruangan mengakibatkan pustakawan tidak memiliki ruang kerja di dalam perpustakaan. Tidak adanya ruang kerja di perpustakaan menjadikan perpustakaan kehilangan fungsi pengawasan dalam pelaksanaan pelayanannya.

Bagi siswa dan guru luas ruangan yang berukuran 20 meter tersebut menjadi penghalan tersendiri untuk melakukan aktivitas di dalam perpustakaan. Guru tidak bisa melaksanakan pembelajaran alternative di dalam perpustakaan, dikarenakan luas yang tidak ruangan yang tidak cukup menampung siswa kelas yang rata-rata berjumlah 20 siswa.

Pustawakan dan guru hendaknya dapat beradaptasi dengan kekurangan ini dengan membuat terobosan yang kreatif dalam pengelolaan dan pemanfaatan perpustakaan. Pustakawan dapat menata koleksi buku dan ruang baca yang seefisien mungkin dengan memanfaatkan setiap sudut ruangan perpustakaan dengan optimal. Pustakawan juga dapat menggunakan peralatan dan perlengkapan yang tidak memerlukan space yang terlalu banyak.

Guru juga masih dapat memanfaatkan perpustakaan selama proses pembelajaran yakni dengan mengkondisikan siswa agar memasuki perpustakaan secara bergantian dengan batasan waktu tertentu, agar semua siswa dapat menggunakan fasilitas perpustakaan tersebut. Solusi lain yang dapat diambil sekolah untuk mengatasi permasalahan luas ruangan perpustakaan ialah dengan membangun sebuah gedung perpustakaan baru dengan luas minimal 56 meter persegi.

\section{Pemilihan Lokasi}

Pemilihan lokasi perpustakaan yang saat ini digunakan berada di sudut sekolah, dekat dengan lapangan upacara dan tidak berada di pusat lalu lintas siswa. Lokasi ini kurang sesuai dengan pernyataan Darmono 
(2004:198) yang menyatakan bahwa salah satu patokan yang harus dipahami dalam menentukan lokasi gedung perpustakaan adalah gedung perpustakaan hendaknya ditempatkan di pusat gedung atau kompleks sekolah, dan tidak jauh dari kelas-kelas, agar mudah dijangkau oleh siswa.

Pertimbangan yang digunakan dalam pemilihan lokasi perpustakaan tersebut lebih banyak didasarkan pada faktor kondisi ruangan dan luas tanah sekolah yang dimiliki oleh sekolah sangat terbatas. Keterbatasan ini mengakibatkan pilihan yang dapat diambil dalam penentuan lokasi perpustakaan menjadi sangat terbatas.

Peneliti berpendapat bahwa lokasi ruang perpustakaan yang saat ini sedang digunakan memang kurang strategis. Perpustakaan sekolah dapat dipindahkan ke ruangan yang berada di pusat aktivitas sekolah dengan cara menggeser kelas yang sudah ada saat ini. Salah satu alternative lain yang dapat diambil ialah dengan membangun gedung perpustakaan baru dengan memanfaatkan lahan kosong di antara kelas 2 dan kelas 3, agar lokasi perpustakaan menjadi lebih strategis.

\section{Pemeliharaan Gedung atau Ruangan}

Peneliti belum menemukan pelaksanaan program pemeliharaan ruang perpustakaan yang dilakukan oleh pustakawan selama masa penelitian. Padahal dalam rencana kegiatan, pustakawan sudah berencana untuk melaksanakan program pemeliharaan ruang perpustakaan. Ketidakterlaksanaan program ini berakibat pada ruang perpustakaan yang kotor dan kurang tertata.

Peneliti berpendapat bahwa program ini seharusnya dapat tetap berjalan, meskipun beberapa kali pustakawan tidak berangkat untuk bertugas. Program pemeliharaan ini dapat berjalan dengan baik apabila pustakawan mau bekerjasama dengan pihak tukang kebun, atau guru serta siswa untuk secacar berkala melakukan pembersihan dan perawatan terhadap ruang perpustakaan sekolah.

Berdasarkan temuan di atas dapat disimpulkan bahwa sekolah telah menyediakan layanan ruang perpustakaan bagi siswa. Layanan sudah dapat digunakan dengan baik, namun masih memiliki beberapa kekurangan seperti ruangan yang kurang luas, lokasi yang kurang strategis, dan program pemeliharaan yang belum berjalan optimal.

Peneliti berpendapat bahwa pembangunan gedung perpustakaan sekolah baru adalah solusi paling tepat untuk mengatasi permasalahan luas ruangan dan kurang strategisnya lokasi ruang perpustakaan. Gedung baru ini dapat terlaksana karena di sudut SDN 13/I Muara Bulian masih memiliki lahan kosong di sudut sekolah yang menjadi pusat aktivitas siswa.

\section{Penyediaan Peralatan dan Perlengkapan Perpustakaan}

Peralatan perpustakaan yang dimiliki oleh sekolah antara lain kartu buku, stempel perpustakaan dan stempel inventaris. Kepemilikan peralatan tersebut belum sesuai dengan pendapat Darmono (2004:216) yang menyatakan bahwa jenis peralatan yang dibutuhkan perpustakaan adalah peralatan habis pakai, peralatan tahan lama, dan peralatan elektronik magnetik. Peralatan perpustakaan sekolah yang harus ada antara lain kartu anggota, kartu peminjaman, pena, kartu buku, kantung buku dan slip tanggal, gunting, penggaris, dan stempel perpustakaan.

Sekolah juga sudah memiliki beberapa perlengkapan perpustakaan, yaitu almari, meja, dan kursi. Perlengkapan yang dimiliki sekolah tersebut belum sesuai dengan pendapat Soeatminah (2002:19) yang menyatakan bahwa kebutuhan perlengkapan perpustakaan meliputi rak buku, meja dan 
kursi baca, meja dan kursi kerja petugas perpustakaan, almari katalog, kereta buku, dan meja peminjaman.

Berdasarkan hasil penelitian di atas, peneliti mengabil kesimpulan bahwa sekolah baru memiliki beberapa peralatan dan perlengkapan perpustakaan yang masih belum sesuai dengan pendapat Darmono (2004:216) dan Soeatmindah (2002:19). Ketersediaan peralatan dan perlengkapan tersebut masih belum mencukupi untuk melaksanakan program pelayanan perpustakaan.

Peneliti berpendapat bahwa keterbatasan peralatan dan perlengkapan tersebut hendaknya disiasati oleh pustakawan dengan memaksimalkan kreativitas yang dimiliki pustakawan. Sebagai contoh pustakawan bisa membuat rak buku dari pipa yang ditempel secara horizontal dan bertingkat-tingkat di dinding perpustakaan. Ruang kosong diatas pipa tersebut di atasnya dapat ditaruh buku-buku sebagai ganti rak buku.

\section{Tata Ruang Perpustakaan}

Pustakawan melakukan penataan ruang perpustakaan berfokus pada penataan meja dan kursi baca dan koleksi bahan pustaka. Pustakawan menempatkan meja dan kursi baca bersebelahan dan dekat dengan koleksi bahan pustaka. Penataan ini sesuai dengan pendapat Ibrahim Bafadal (2005:163) yang menyatakan bahwa penataan meja dan kursi belajar yang baik diintegrasikan dengan tempat atau rak-rak buku.

Penataan ruang perpustakaan juga sudah memperhatikan penerangan dan sirkulasi udara. Pustakawan tidak melakukan penataan kerja ruang petugas dikarenakan tidak adanya space kosong yang dapat digunakan sebagai tempat kerja pustakawan.Penempatan buku pun sudah mempertimbangkan faktor keamanan dengan menghindarkan dari kemungkinan bocornya atap.

Peneliti berpendapat bahwa usaha penataan tata ruang perpustakaan masih mudah dilakukan oleh pustakawan. Kemudahan penataan ini disebabkan oleh minimnya peralatan, perlengkapan, dan koleksi bahan pustaka yang dimiliki perpustakaan.

\section{Koleksi bahan pustaka}

Koleksi bahan pustaka yang dimiliki sekolah antara lain koleksi bahan pustaka berupa buku dan non buku. Sekolah juga telah memiliki koleksi bahan pustaka yang berisi fiksi dan non fiksi. Ketersediaan koleksi tersebut sudah sesuai dengan pendapat Ibrahim Bafadal (2005:27) yang membagi jenis bahan pustaka berdasarkan bentuk fisik dan isinya.

Adanya kelengkapan bahan pustaka di atas sangat penting sebagai sumber belajar alternatif siswa. Namun jumlah koleksi yang dimiliki oleh perpustakaan sekolah tidak seimbang. Jumlah buku pelajaran di perpustakaan mencapai setengah dari jumlah koleksi bahan pustaka yang dimiliki perpustakaan, sedangkan jumlah koleksi bahan pustaka lain masih sangat sedikit.

Peneliti berpendapat bahwa pustakawan seharusnya dapat aktif mencari koleksi bbahan pustaka tambahan. Penambahan bahan pustaka ini dapat dilakukan tanpa membutuhkan biaya, dikarenakan ada beberapa program dari percetakan buku yang mau menyumbangkan bukunya untuk keperluan pendidikan baik di desa maupun di sekolah. Apabila pustakawan dapat memaksimalkan peluang itu, permasalahan kurang lengkapnya koleksi bahan pustaka perpustakaan dapat teratasi.

\section{Tenaga Pustakawan}

Keberadaan pustakawan ini sudah bagus karena sesuai dengan pendapat Soeatminah (2002:20) yang menjelaskan 
bahwa perpustakaan tanpa senorang pustakawan atau tenaga yang mampu dan terampil melakukan tugas kepustakawanan akan merupakan koleksi kertas bekas.

Kepala sekolah memberikan tugas kepada pustakawan untuk mengelola ruang, koleksi bahan pustaka, dan perangkat perpustakaan. Pelaksanaan tugas pustakawan dalam mengelola buku sudah berjalan sampai tahap buku telah dilayankan di perpustakaan, namun pustakawan belum melengkapi tahap komputerisasi bahan pustaka. Pustakawan juga sudah membuat perangkat perpustakaan berupa buku daftar pengunjung perpustakaan, dan kartu anggota perpustakaan, tetapi baru sebatas desain dan belum sampai tahap pencetakan.

Peneliti berpendapat bahwa peran pustakawan sudah bagus, meskipun belum maksimal. Pustakawan telah melakukan tugasnya dalam pengelolaan perpustakaan, namun karena beberapa fasilitas yang belum lengkap serta minimnya dana yang dialokasikan oleh sekolah untuk keperluan perpustakaan mengakibatkan belum terselesaikannya keseluruhan tugas yang dimiliki oleh pustakawan.

\section{Pembiayaan}

Sumber dana utama pembiayaan pengelolaan perpustakaan berasal dari dana BOS (Bantuan Operasional Sekolah). Selain itu ada juga dana lain yang bisa digunakan yakni melalui pengajuan proposal bantuan melalui dinas pendidikan. Model pembiayaan ini sudah sesuai dengan pendapat Noerhayati (1998:128) yang menyatakan bahwa perpustakaan membutuhkan pembiayaan yang harus disediakan oleh pemerintah yang besaran biayanya ditentukan berdasarkan banyaknya siswa. Adanya alokasi pembiayaan tersebutsudah sangat membantu dalam pengelolaan perpustakaan apabila dapat dilaksanakan secara konsisten. Namun dalam pelaksanaannya besar pembiayaan dari BOS untuk pembiayaan pengelolaan perpustakaan tidak menentu setiap tahunnya. Sekolah seharusnya dapat menetapkan anggaran secara konsisten yang akan dialokasikan untuk pengelolaan perpustakaan.

Dukungan pembiayaan pengelolaan yang baik oleh sekolah menurut peneliti adalah dukungan yang sangat penting baik untuk memenuhi keperluan pengelolaan perpustakaan dan sebagai dukungan moril bagi pustakawan untuk dapat bekerja dengan maksimal sesuai dengan perannya.

\section{Pelayanan perpustakaan}

Sekolah telah melaksanakan pelayanan perpustakaan setiap hari selama jam sekolah berlangsung. Layanan perpustakaan yang diberikan sekolah yaitu layanan peminjaman bahan pustaka, layanan referensi, dan layanan fasilitas ruang baca.Pelaksanaan layanan perpustakaan ini masih belum diawasi dan dilayani oleh pustakawan, sehingga siswa yang mau meminjam dibebaskan untuk meminjam bahan pustaka secara mandiri.

Pelaksanaan layanan di atas sudah
sesuai dengan pendapat Darmono (2004:141) yang menyebutkan tentang jenisjenis layanan yang harus ada dalam perpustakaan sekolah meliputi layanan peminjaman bahan pustaka, layanan referensi, dan layanan ruang baca. Adanya layanan di atas sangat membantu sekali dalam memfasilitasi minat baca siswa di sekolah. Namun, belum adanya pengawasan dan pelayanan dari pustakawan dapat menjadi masalah yang cukup serius.

Peneliti berpendapat bahwa banyak kerugian yang hilang dari tidak adanya pengawasan terhadap pelayanan perpustakaan. Resiko rusak dan hilangnya bahan pustaka adalah kerugian yang dapat timbul dari belum adanya pengawasan dalam pelaksanaan pelayanan perpustakaan. Perpustakaan juga akan kesulitan untuk 
melakukan evaluasi terhadap efektivitas pelayanan yang telah dijalankan.

\section{Tata Tertib Perpustakaan}

Pelaksanaan tata tertib di perpustakaan belum berjalan optimal. Tata tertib yang dimiliki sekolah sendiri belum jelas, karena belum ada tata tertib perpustakaan yang tertulis dan tertempel di perpustakaan. Tata tertib hanya disampaikan pihak sekolah secara lisan. Penegakkan tata tertib dengan pemberian sanksi pun juga belum dilaksanakan.

Ibrahim Bafadal

(2005:24)

menjelaskan bahwa ada hal-hal penting yang perlu dicantumkan dalam tata tertib, yaitu sifat dan status perpustakaan, keanggotaan perpustkaan sekolah, bahan-bahan pustaka yang tersedia, sanksi atau hukuman bagi pengunjung yang melanggar tata tertib, iuran bagi setiap anggota, waktu pelayanan, sistem penyelenggaraan, serta batas waktu dan jumlah buku boleh dipinjam.

Penempelan tata tertib ini sangat penting dalam kaitannya membentuk sikap disiplin siswa dalam menggunakan fasilitas perpustakaan sekolah. Sekolah menurut peneliti sesuai dengan pemahaman Ibrahim Bafadal di atas seharusnya menuliskan dan menempel tata tertib di papan dan kemudian dipajang di perpustakaan. Penempelan tata tertib dapat menjadi pengingat bagi siswa terhadap hal-hal yang harus diperhatikan ketika menggunakan layanan perpustakaan.

\section{SIMPULAN}

Beberapa aspek pengelolaan perpustakaan masih memiliki banyak kekurangan, seperti :

1. Gedung yang belum memenuhi syarat,

2. Peralatan dan perlengkapan yang belum lengkap,

3. Tata ruang perpustakaan,

4. Koleksi bahan pustaka masih sedikit,

5. Kurangnya tenaga pustakawan,

6. Pelayanan yang masih belum diawasi, dan
7. Belum adanya tata tertib perpustakaan yang jelas.

8. Hal-hal tersebut membuat siswa kurang terdorong untuk menjadikan perpustakaan sebagai sumber belajar.

Berdasarkan uraian diatas, maka dapat disimpulkan bahwa pelaksanaan pengelolaan perpustakaan sebagai sumber belajar belum berjalan secara optimal.

\section{DAFTAR PUSTAKA}

Bafadal, Ibrahim. (2005). Pengelolaan Perpustakaan Sekolah. Jakarta: Bumi Aksara

Darmono. (2004). Manajemen dan Tata Kerja Perpustakaan Sekolah. Jakarta: Grasindo

Depdikbud. (1986). Buku Pedoman Pembakuan Bangunan Sekolah, Proyek Pembakuan Sarana Pendidikan. Jakarta: Depdikbud

F. Rahayuningsih. (2007). Pengelolaan Perpustakaan. Yogyakarta: Graha Ilmu

Muhibinsyah. (2006). Psikologi Belajar. Jakarta: Penerbit Raja Grafindo Persada

Noerhayati. (1987). Pengelolaan Perpustakaan. Bandung: Alumni

$$
\text { (1988). Pengelolaan }
$$

Perpustakaan Jilid II. Bandung: Alumni

Riduwan (2010). Skala Pengukuran Variabel-Variabel Penelitian, Alfabeta, Bandung.

Rohani. (1997). Media Instruksional Edukatif. Jakarta: PT Rineka Cipta

Rohani, dkk. (1991). Pengelolaan Pengajaran. Jakarta: PT Rineka Cipta

Soeatminah. (1992). Perpustakaan, Kepustakawanan dan Pustakawan. Yogyakarta: Kanisius

Sudono, Anggani. (2004). Sumber Belajar dan Alat Permainan untuk Pendidikan Usia Dini. Jakarta: PT Grasindo 
Sugihartono, dkk. (2007). Psikologi Pendidikan. Yogyakarta: UNY Press

Sugiyono. (2009). Metode Penelitian Kuantitatif, Kualitatif, dan $R \& D$. Bandung: Alfabeta

Suharjo. (2006). Mengenal Pendidikan Sekolah Dasar Teori dan Praktek. Jakarta : Departemen Pendidikan Nasional Direktorat Jenderal Pendidikan Tinggi Direktorat Ketenagaan.

Sumantri, M.T. (2008). Panduan Penyelenggaraan Perpustakaan Sekolah. Bandung: PT Remaja Rosdakarya

Sutarno, NS. (2006). Perpustakaan dan Masyarakat. Jakarta : CV. Sagung Seto

Sudjana dan Rivai. (2006). Media Pengajaran. Bandung: PT SinarBaru Algesindo

Sukmadinata. (2010). Metode Penelitian Pendidikan. Bandung: Remaja Rosdakarya

Sinaga. (2011). Mengelola Perpustakaan Sekolah. Bandung: Bejana 